\begin{tabular}{lr}
\hline \multicolumn{1}{c}{ D Y N A M I C E C O N O M E T R I C } & M O D E L S \\
DOI: http://dx.doi.org/10.12775/DEM.2014.005 & Vol. 14 (2014) 93-104 \\
\hline $\begin{array}{l}\text { Submitted October 20, 2014 } \\
\text { Accepted December 23, } 2014\end{array}$ \\
ISSN \\
1234-3862
\end{tabular}

Ewa M. Syczewska*

\title{
The EURPLN, DAX and WIG20: The Granger Causality Tests Before and During the Crisis
}

\begin{abstract}
A bstract. In this paper the possible interdependence between bilateral exchange rate behavior and the corresponding stock indices is checked, with application to the EURPLN rate and the DAX and WIG20 stock indices. Methods and results are similar to previous study of USDPLN exchange rate, and SP500 and WIG20 indices. The linear (including instantaneous) causality test and the Diks-Panchenko test are applied to logarithmic returns and to the daily measure of volatility $r_{t}=\ln \left(\frac{P_{\max , t}}{P_{\min , t}}\right)$. Differences between before- and during-crisis period results are less vivid than in case of the U.S. and the Polish instruments. But there is a substantial difference between linear (and Diks-Panchenko) test results and the instantaneous Granger-causality test results, on the other hand - between returns and daily volatility.
\end{abstract}

K e y w o r d s: Exchange rates, stock indices, financial crisis, risk, Granger causality, instantaneous causality, Diks-Panchenko test.

J E L Classification: C4, G19.

\section{Introduction}

The results presented here are part of the research aimed at detecting interdependencies between bilateral exchange rates and stock indices of the corresponding two countries, while possible influence of the crisis is taken into account. The idea of improvement of the exchange rate model by use of the stock indices from the corresponding two countries has been suggested

\footnotetext{
${ }^{*}$ Correspondence to: Ewa M. Syczewska, Warsaw School of Economics, Collegium of Economic Analysis, Institute of Econometrics, 6/8 Madalinskiego Street, 02-513 Warsaw, Poland, e-mail: Ewa.Syczewska@sgh.waw.pl.

C) 2014 Nicolaus Copernicus University. All rights reserved. http://www.dem.umk.pl/dem
} 
by the Bauwens et al. (2008) model of the Norwegian krona, and used with success in the previous research by the author. In Syczewska (2010, 2013, 2014) this method and the Granger linear causality tests were applied to the USD/PLN daily data and two indices - one from the Warsaw Stock Exchange, the other representing the U.S. stock indices. It was shown that forecast errors from the ARIMA and GARCH models diminished when the stock indices were included in the model as additional explanatory variables (see also Matuszewska and Witkowska (2007) for comparison to other methods of forecasting).

In Syczewska (2013) research it was shown that it is possible to find a stationary relationship between the USDPLN exchange rate and the U.S. and Polish stock indices. As the U.S. stock exchange opens before the closing time of the Warsaw Stock Exchange, it was decided to use opening values of the S\&P500 stock index and the closing values both for the USDPLN exchange rate and for the WIG stock index. There was a linear combination of the three variables, for which hypothesis of nonstationarity had to be rejected.

In this paper we first perform the Granger causality tests for the EURPLN exchange rate and two stock indices: DAX and WIG20. We check whether the stock-index returns Granger-cause the relative changes of the exchange rate. To this aim we use both the Granger test and the Granger test of instantaneous causality ${ }^{1}$. To take into account possible effects of the crisis, we perform the causality tests and the estimation exercise for two subsamples: up to Sept. 15th 2008 ("before crisis") and since Sept. 16th 2008 ("during crisis"). Next we apply to the same variables the Diks-Panchenko causality test, which is assumed to detect also nonlinear causality.

We use daily data provided by stooq.pl, choose the period since the beginning of May 2004 (corresponding to the EU accession) up to beginning of October 2013. In Syczewska (2010) behavior of rates and quality of modeling was compared for two subperiods: before (up to September 2008) and during crisis (up to end of July 2009), showing that ${ }^{2}$ :

1. Volatility of returns, hence errors of forecasts from the ARMA and GARCH models of returns, hugely increased during the crisis.

2. Introduction of corresponding stock indices returns slightly improved performance of the models and forecasts.

\footnotetext{
${ }^{1}$ This was suggested by specification of models for daily returns of Norwegian krona (Bauwens et al., 2008).

2 The paper by Syczewska (2010) was presented at the International Conference "Zagadnienia aktuarialne - teoria i praktyka" in Warsaw, $2^{\text {nd }}-4^{\text {th }}$ September 2009.
} 
The Polish economy performance during the crisis was better than for the other European economies. The current condition of the German economy (the main trade partner of Poland) and expectations of future development give hope for further improvement. The EURPLN exchange rate is important for the economic analysis due to the proportion of transactions made in Euro.

\section{Description of the Data}

We use daily data since 4th May 2004 (the EU accession) until September 2008 and from September 2008 until the September 2013 for the indices and exchange rates, and for the sake of comparison we perform the tests to the data from the first period ("before the crisis"), and the second period ("during the crisis") starting in mid-September 2008, with the same number of observations as the first one ${ }^{3}$. As a measure of returns we use the standard formula:

$$
z_{t}=100 *\left(\ln y_{t}-\ln y_{t-1}\right),
$$

where $y_{t}$ - closing values of an instrument, and also logarithm of proportion of daily maximum and minimum:

$$
\sigma_{t}^{2}=100 * \ln \left(y_{\max , t} / y_{\min , t}\right),
$$

as a measure of variance/volatility (Brooks, 2008). Figure 1 shows a typical behavior of the DAX index returns: there is a marked increase of volatility during the 2008-09 crisis, later slight stabilization and again increase of volatility due to problems of the Euro zone. Figure 2 illustrates measure of volatility of the same stock index defined by equation (2). There is a marked increase in volatility during the subprime crisis and subsequent global crisis on financial markets. Next, in the year 2009, the situation seems to slightly stabilize, but later due to the problems in the Euro area, volatility increases again.

The summary statistics in the Tables 1 and 2, corresponding to the "precrisis" and "crisis" periods, show that the distribution of the logarithmic returns and returns (2) are skewed, which has to be expected. The results of the Doornik-Hansen test show that the empirical distribution of all the variables is non-Gaussian. Note that the empirical distribution of volatility, rDAX etc. defined by eqn. (2), is more skewed than the distribution of logarithmic returns for the same instrument.

\footnotetext{
${ }^{3} \mathrm{http} / / /$ stooq.pl database, opening, closing, minimum and maximum daily quotes. We use only the dates, for which all the quotes of variables of interest were available.
} 


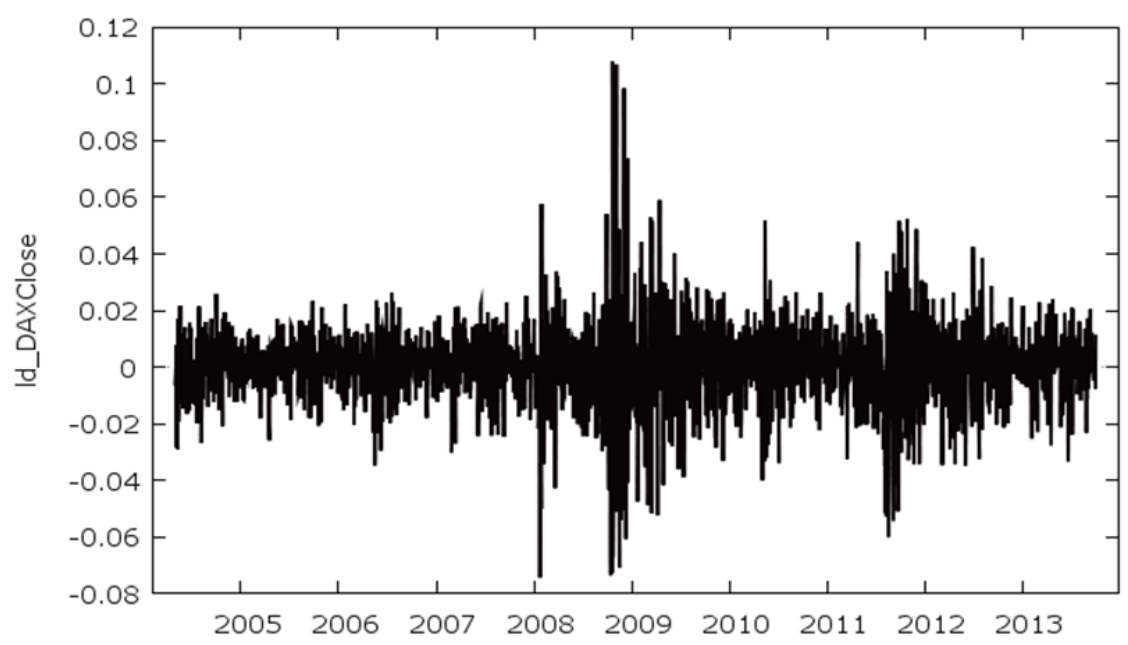

Figure 1. Logarithmic returns of the DAX index

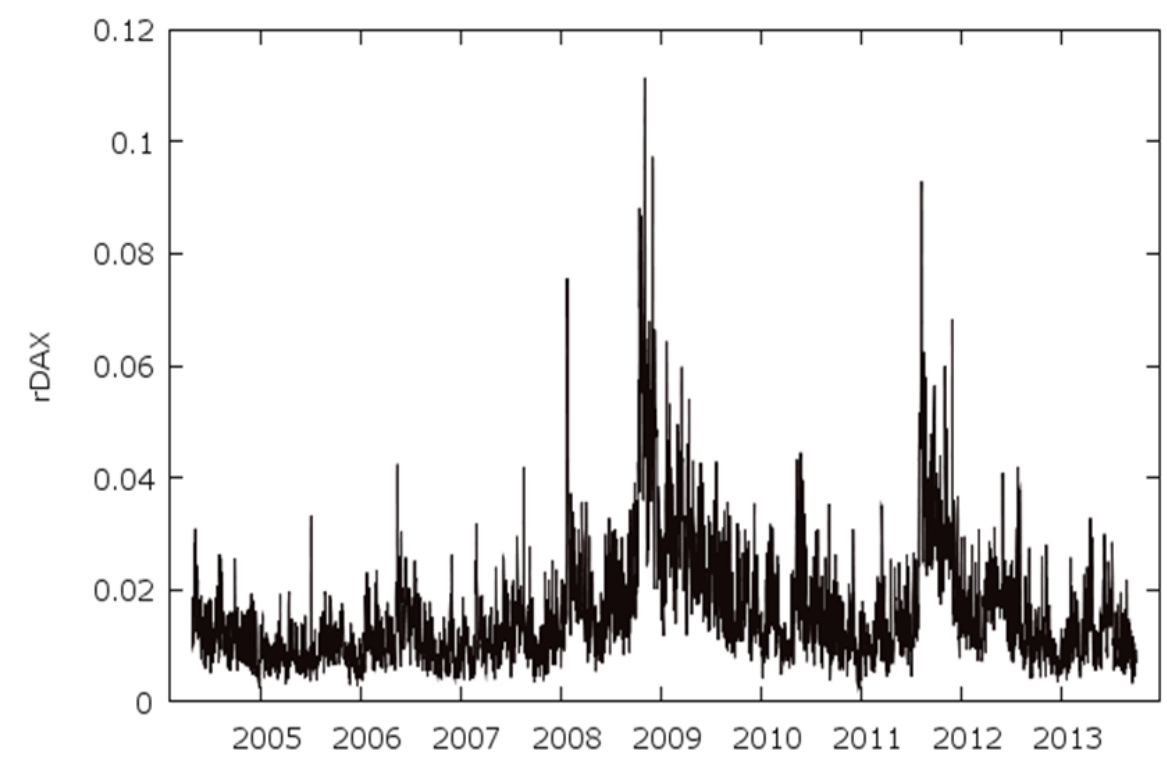

Figure 2. Volatility as in (2) of the DAX index

During the subprime, global and Euro area crisis the volatility substantially increases. The last column of Table 2 gives a measure of this increase, computed as a relative change of standard deviations for the second as com- 
pared to the first subsample. The increase is close to $25 \%$ for the WIG20 returns, and around $70 \%$ for the EURPLN exchange rate and the DAX index. The volatility (2) increases are even higher, by $60 \%$ for WIG20, almost $100 \%$ for the DAX index and almost $130 \%$ for the EURPLN exchange rate.

Table 1. Summary statistics, 1098 daily observations from $30^{\text {th }}$ Apr. 2004 to $15^{\text {th }}$ Sept. 2008 ("before crisis")

\begin{tabular}{ccccccc}
\hline Variable & Mean & Median & Std. Dev. & Skewness & Kurtosis & $\begin{array}{c}\text { Doornik- } \\
\text { Hansen } \\
\text { test }\end{array}$ \\
\hline Id_EURPLN & -0.0323 & -0.0361 & 0.46162 & 0.1670 & 1.4535 & 67.946 \\
Id_DAX & 0.0377 & 0.1084 & 1.0459 & -0.5392 & 3.8284 & 238.571 \\
Id_WIG20 & 0.0274 & 0.0696 & 1.4138 & -0.2944 & 1.4172 & 61.228 \\
rDAX & 1.2353 & 1.0810 & 0.69478 & 2.7689 & 16.812 & 696.955 \\
rWIG20 & 1.7240 & 1.5224 & 0.84969 & 1.9266 & 6.7395 & 568.593 \\
rEURPLN & 0.6831 & 0.6207 & 0.31109 & 1.5026 & 4.3757 & 329.235 \\
\hline
\end{tabular}

\section{The Granger Causality Test}

The Granger test of the Granger causality, applied to the returns of the exchange rate and the corresponding stock indices, can be treated as a tool for choice of explanatory variables in the model for exchange rates. According to the well-known definition, a variable $X$ is called a Granger-cause for a variable $Y$, if lagged values of $X$ used as additional regressors in a model describing $Y$ can improve quality of model and/or forecasts ${ }^{4}$. There are several tests of this property. Let $y_{t}$ denote observation of the $Y$ variable for period $t, y_{t-i}, i=1,2, \ldots, k$ - lagged observations for the same variable, $x_{t-j}, j=0,1,2, \ldots, k-$ current and lagged values of $X, a_{1 i}, b_{1 j}$, $i=1,2, \ldots, k, j=0,1,2, \ldots, k$-parameters of the model, $\varepsilon_{t}$ - error terms.

The Granger test of Granger causality is based on VAR - type regressions (regression of $Y$ on its lagged values and the same lags of the $X$ variable):

$$
y_{t}=a_{11} y_{t-1}+\ldots+a_{1 k} y_{t-k}+b_{11} x_{t-1}+b_{12} x_{t-2}+\ldots+b_{1 k} x_{t-k}+\varepsilon_{t} .
$$

The null $\mathrm{H}_{0}: b_{11}=b_{12}=\ldots=b_{1 k}=0$ means that the $X$ does not Granger-cause the $Y$ variable. Another variant is so-called instantaneous causality: the regression includes current value of the $X$ variable:

\footnotetext{
${ }^{4}$ But see also the detailed discussion of Granger causality concepts and their interpretation in Osińska $(2008,2011)$.
} 


$$
y_{t}=a_{11} y_{t-1}+\ldots+a_{1 k} y_{t-k}+b_{10} x_{t}+b_{11} x_{t-1}+b_{12} x_{t-2}+\ldots+b_{1 k} x_{t-k}+\varepsilon_{t} .
$$

The null $\mathrm{H}_{0}: b_{10}=b_{11}=b_{12}=\ldots=b_{1 k}=0$ in (4) means that $X$ is not an instantaneous cause for $Y$.

Table 2. Summary statistics, 1098 daily observations from the period 16 Sept. 2008 to 1rd Feb. 2013 ("during crisis")

\begin{tabular}{|c|c|c|c|c|c|c|c|}
\hline $\begin{array}{l}\frac{0}{\frac{0}{0}} \\
\frac{\sqrt{\frac{\pi}{5}}}{\infty} \\
\frac{10}{3}\end{array}$ & $\begin{array}{l}\text { đ్ } \\
\stackrel{\mathbb{J}}{\Sigma}\end{array}$ & 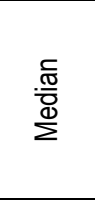 & $\begin{array}{l}\text { के } \\
\text { वे } \\
\text { के }\end{array}$ & 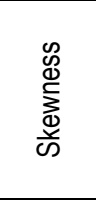 & $\begin{array}{l}\frac{n}{00} \\
\frac{0}{5} \\
\frac{1}{2}\end{array}$ & 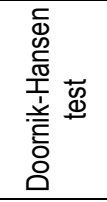 & 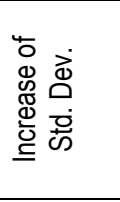 \\
\hline IdEURPLN & 0.0197 & -0.019 & 0.812 & 0.040 & 2.963 & 216.86 & $75.97 \%$ \\
\hline $\operatorname{IdDAX}$ & 0.0233 & 0.089 & 1.754 & 0.123 & 5.389 & 507.16 & $67.68 \%$ \\
\hline IdWIG20 & 0.0051 & 0.057 & 1.756 & -0.289 & 3.150 & 217.24 & $24.19 \%$ \\
\hline rDAX & 2.0195 & 1.638 & 1.384 & 2.212 & 7.333 & 1074.24 & $99.16 \%$ \\
\hline rWIG20 & 1.9622 & 1.552 & 1.359 & 2.544 & 10.458 & 1224.63 & $59.95 \%$ \\
\hline rEURPLN & 1.0716 & 0.850 & 0.715 & 2.283 & 7.116 & 1382.02 & $129.80 \%$ \\
\hline
\end{tabular}

The results of the Granger causality tests for the EURPLN exchange rate returns and the corresponding German and Polish stock indexes returns are the following. (We use LS estimates with robust standard errors; p-values are given in brackets.)

\subsection{Comparison of Results for Periods Before and During the Crisis}

First we perform the test for subperiod between 2004-2008, i.e. before the crisis (more precisely: since 29 April 2004 until $15^{\text {th }}$ Sept. 2008, 1098 observations), and compare the results for a similar subsample (with the same number of observations) starting on $16^{\text {th }}$ Sept. 2008, and ending at $2^{\text {nd }}$ Feb. 2013. For each pair of the variables the VAR model was estimated. The $F(\cdot, \cdot)$ test statistic presented in the second and third column of the Table 3 corresponds to the null hypothesis that all lags of the explanatory variable are insignificant in the equation for the dependent variable. Next, in order to test instantaneous Granger causality, we estimate the regression (4) using the OLS with heteroskedasticity and autocorrelation consistent standard errors, and test the restriction $\mathrm{H}_{0}: b_{10}=b_{11}=b_{12}=\ldots=b_{1 k}=0$. The results of this test for both periods are given in Table 4 .

In case of pre-crisis period, the null of no causality was not rejected, for data covering the crisis period, only in one case - namely the causality from the EURPLN exchange rate returns to the WIG20 stock index returns, the null of causality has not been rejected (see Table 3). The results of the linear 
Granger instantaneous causality test are different. The null hypothesis of lack of causality has been rejected in all the cases (see Table 4).

Table 3. Linear Granger causality before and during the crisis

\begin{tabular}{ccc}
\hline Causality & \multicolumn{2}{c}{ The test statistic [p-value] } \\
\hline Pair of variables & Before the crisis & During the crisis \\
\hline IdDAX to IdEURPLN & $0.550[0.731]$ & $0.217[0.955]$ \\
IdEURPLN to IdDAX & $1.521[0.180]$ & $1.032[0.397]$ \\
IdWIG20 to IdEURPLN & $0.880[0.494]$ & $0.771[0.571]$ \\
IdEURPLN to IdWIG20 & $1.648[0.145]$ & $3.660[0.0027]^{\star * *}$ \\
IdDAX to IdWIG20 & $0.984[0.427]$ & $1.5016[0.187]$ \\
IdWIG20 to IdDAX & $0.469[0.800]$ & $0.283[0.923]$ \\
\hline
\end{tabular}

Table 4. Instantaneous Granger causality before and during the crisis

\begin{tabular}{|c|c|c|}
\hline Instantaneous causality & \multicolumn{2}{|c|}{ The test F-statistic [p-value] } \\
\hline Pair of variables & Before the crisis & During the crisis \\
\hline IdDAX to IdEURPLN & $10.875[8.798 \mathrm{e}-012]^{\star \star \star}$ & $46.066[2.090 \mathrm{e}-050]^{\star \star *}$ \\
\hline IdEURPLN to IdDAX & $9.652[2.279-010]^{\star * *}$ & $27.905[4.170 \mathrm{e}-031]^{\star \star *}$ \\
\hline IdWIG20 to IdEURPLN & $15.021[1.439 \mathrm{e}-016]^{\star * *}$ & $31.744[2.636 \mathrm{e}-035]^{\star \star *}$ \\
\hline IdEURPLN to InWIG20 & $11.026[5.888-012]^{\star * *}$ & $47.805[3.519 \mathrm{e}-052]^{\star * *}$ \\
\hline IdWIG20 to IdDAX & $36.004[6.862-040]^{\star * *}$ & $75.458[8.618 \mathrm{e}-079]^{\star \star *}$ \\
\hline IdDAX to IdWIG20 & $54.246[1.215-058]^{\star \star *}$ & $116.092[3.142 \mathrm{e}-113]^{* * *}$ \\
\hline
\end{tabular}

\section{Linear Causality Tests for the Volatility Measure (2)}

The similar computations of the linear Granger test have been repeated using the volatility measure (2) instead of the log returns. Before the crisis the linear test indicates causal relation only from volatility of WIG20 to one of the DAX stock index (and we would expect the influence to work the other way round). During the crisis the null hypothesis of lack of causality is rejected for all pairs of instruments with exception of rDAX to rEURPLN and to rWIG20 (see Table 5).

Table 5. The Granger causality test for volatility measure (2)

\begin{tabular}{ccc}
\hline Causality & \multicolumn{2}{c}{ The test statistic [p-value] } \\
\hline Pair of variables & Before the crisis & During crisis \\
\hline rDAX to rEURPLN & $1.1059[0.3554]$ & $1.7194[0.1273]$ \\
rEURPLN to rDAX & $0.8221[0.5339]$ & $2.5659[0.0256]^{\star *}$ \\
rWIG20 to rEURPLN & $1.2961[0.2631]$ & $3.0783[0.0091]^{\star * *}$ \\
rEURPLN to rWIG20 & $0.1288[0.9859]$ & $2.4572[0.0317]^{\star *}$ \\
rDAX to rWIG20 & $0.5797[0.7156]$ & $1.4111[0.2175]$ \\
rWIG20 to rDAX & $2.4223[0.0340]^{* *}$ & $2.4853[0.0300]^{* *}$ \\
\hline
\end{tabular}


Table 6. The instantaneous causality linear test

\begin{tabular}{ccc}
\hline Instantaneous causality & \multicolumn{2}{c}{ The test statistic [p-value] } \\
\hline & Before the crisis & During the crisis \\
\hline rDAX to rEURPLN & $3.934[0.0006]^{\star \star *}$ & $11.447[1.92 \mathrm{e}-12]^{\star \star *}$ \\
rEURPLN to rDAX & $2.251[0.0365]^{\star *}$ & $9.099[9.91 \mathrm{e}-10]^{\star * *}$ \\
rWIG20 to rEURPLN & $1.886[0.0801]^{\star}$ & $8.247[9.50 \mathrm{e}-09]^{\star * *}$ \\
rEURPLN to rWIG20 & $0.734[0.6222]$ & $5.999[3.48 \mathrm{e}-06]^{\star * *}$ \\
rDAX to rWIG20 & $23.263[6.06 \mathrm{e}-26]^{\star * *}$ & $24.122[6.61 \mathrm{e}-27]^{\star * *}$ \\
rWIG20 to rDAX & $9.934[1.08 \mathrm{e}-10]^{* * *}$ & $17.241[4.07 \mathrm{e}-19]^{\star \star *}$ \\
\hline
\end{tabular}

The results of the instantaneous causality test before the crisis are in better agreement with the intuition. There is a strong influence from rDAX to the exchange rate, weaker from rWIG20 to rEURPLN, and feedback between the two stock indices (see the second column of the Table 6). Last column of the same Table shows results indicating strong feedback between all pairs of variables.

\section{The Diks-Panchenko Causality Test}

The improved version of nonlinear Hiemstra-Jones test was introduced by Diks and Panchenko (2006). The idea of this nonparametric test is the following: The variable $X$ Granger-causes the $Y$, if the current and lagged values of the $X: x_{t}, x_{t-1}, \ldots, x_{t-k}$ contain information concerning the future values $y_{t+1}, y_{t+2}, \ldots$, additional to that contained in current and past values of this variable. In their paper Diks and Panchenko test conditional independence of finite number of lags:

$$
Y_{t+1}\left|\left(X_{t}, X_{t-1}, \ldots, X_{t-l_{x}+1}, Y_{t}, Y_{t-1}, \ldots, Y_{t-l y+1}\right) \sim Y_{t+1}\right|\left(X_{t}, X_{t-1}, \ldots, X_{t-l X+1}\right),
$$

where $l_{X}, l_{Y}$ denote numbers of lags of the variables $X$ and $Y$, respectively. The Diks-Panchenko test is an improved version of the Hiemstra-Jones test, based on comparison of the conditional distributions ${ }^{5}$.

Diks and Panchenko use one lag for the variables and the $Y_{t+1}$ forecast for the next period. Let $\left(X_{t}, Y_{t}, Y_{t+1}\right)=(X, Y, Z)$ and assume that $X$ and $Y$ are strictly stationary variables. The null hypothesis of lack of causality means that the conditional distribution of $Z$ with respect to $Y$ and $X$ is the same as the conditional distribution of $Z$ with respect to $Y$ alone. The joint distribution and the marginal distributions are described by the formula

${ }^{5}$ More detailed analysis of this test can be found in Osińska (2008), pp. 226-229. 
$f_{X, Y, Z}(x, y, z) / f_{X, Y}(x, y)=f_{Y, Z}(y, z) / f_{Y}(y)$. Diks and Panchenko (2006) show some deficiencies of the Hiemstra and Jones approximation of both sides of this formula, and propose their own versions: the null hypothesis of lack of causality implies that

$$
q_{g} \equiv E\left[\left(\frac{f_{X, Y, Z}(X, Y, Z)}{f_{Y}(Y)}-\frac{f_{X, Y}(X, Y)}{f_{Y}(Y)} \frac{f_{Y, Z}(Y, Z)}{f_{Y}(Y)}\right) g(X, Y, Z)\right]=0,
$$

where $g(X, Y, Z)$ denotes a positive weights function, e.g. for $g(X, Y, Z)=f_{Y}^{2}(Y)$ this simplifies to:

$$
q_{g} \equiv E\left[f_{X, Y, Z}(X, Y, Z) f_{Y}(Y)-f_{X, Y}(X, Y) f_{Y, Z}(Y, Z)\right] .
$$

Under the null, the expression in parentheses is equal to zero, hence (5) is equal to zero. The null of no causality is rejected if the test statistic is high. Diks and Panchenko (2006) advocate use for (5) of the following estimator based on index function

$$
T_{n}(\varepsilon)=\frac{(2 \varepsilon)^{-d_{X}-d_{Y}-d_{Z}}}{n(n-1)(n-2)} \sum_{i}\left[\sum_{k, k \neq i} \sum_{j, j \neq 1}\left(I_{i k}^{X, Y, Z} I_{i j}^{Y}-I_{i k}^{X Y} I_{i j}^{Y Z}\right)\right],
$$

where:

$n$ - number of observations, $d_{X}$ - number of elements of the $X$ vector etc.,

$I_{i, j}^{W}$ is the index function $I_{i, j}^{W}=I\left(|| W_{i}-W_{j}||<\varepsilon\right)$ is equal to 1 if $\left\|W_{i}-W_{j}\right\|<\varepsilon$ and to 0 otherwise,

$\|\cdot\|$ denotes the supremum norm.

Diks and Panchenko give formula for choice of the $\varepsilon$ (bandwith) depending on number of observations (the default value is 0.5 ). They show that when $d_{X}=d_{Y}=d_{Z}=1$, the estimator is consistent and has asymptotic Gaussian distribution. Their code for application of the test both for Linux and for Windows is available at the Panchenko's webpage:

http://research.economics.unsw.edu.au/vpanchenko/software/2006_GC_JED C_c_and_exe_code.zip.

\section{The Results of the Diks-Panchenko Test}

In our computations we assume 0.5 bandwidth, and we compute the $T_{n}$ statistic for one lag. The results are the following (see Table 7). During the 
crisis, the null of lack of causality is strongly rejected for all pairs of variables. For period 2004-2008, "before the crisis", the test does not indicate causal relationship for logarithmic returns, with only exception of ldDAX $\rightarrow$ ldWIG20 influence (the upper part of the Table 7). In case of our volatility measure, the $T_{n}$ test statistic indicates feedback between rDAX and rWIG20, and some influence from rWIG20 towards rEURPLN (the lower part of the Table 7), all at $10 \%$.

Table 7. The Diks-Panchenko causality test

\begin{tabular}{|c|c|c|}
\hline \multirow{2}{*}{$\begin{array}{c}\text { Causality for variables } \\
\text { Logarithmic returns }\end{array}$} & \multicolumn{2}{|c|}{$\begin{array}{l}\text { The Diks-Panchenko test statistics } \\
\text { [p-value] }\end{array}$} \\
\hline & Before the crisis & During the crisis \\
\hline$\neg \mathrm{IdDAX} \rightarrow \mathrm{IdEURPLN}$ & $0.479[0.3158]$ & $2.697[0.0035]^{\star * *}$ \\
\hline$\neg$ IdEURPLN $\rightarrow$ IdDAX & $-0.661[0.7458]$ & $3.506[0.00023]^{* * *}$ \\
\hline$\neg \mathrm{IdDAX} \rightarrow \mathrm{IdWIG} 20$ & $1.541[0.0617]^{*}$ & $3.589[0.0017]^{* * *}$ \\
\hline$\neg \mathrm{IdWIG} 20 \rightarrow \mathrm{IdDAX}$ & $-0.916[0.8202]$ & $3.118[0.0009]^{\star * *}$ \\
\hline$\neg \mathrm{IdEURPLN} \rightarrow \mathrm{IdWIG} 20$ & $-0.760[0.7763]$ & $3.625[0.0014]^{\star \star *}$ \\
\hline$\neg \mathrm{ldWIG20} \rightarrow \mathrm{IdEURPLN}$ & $-1.648[0.9503]$ & $2.525[0.0056]^{\star * *}$ \\
\hline $\ln (\operatorname{maxPt} / \operatorname{minPt})$ & Before the crisis & During the crisis \\
\hline$\neg \mathrm{rDAX} \rightarrow \mathrm{rEURPLN}$ & $-1.104[0.8652]$ & $2.922[0.0017]^{* \star *}$ \\
\hline$\neg \mathrm{rEURPLN} \rightarrow \mathrm{rDAX}$ & $-1.253[0.8949]$ & $3.612[0.0002]^{* * *}$ \\
\hline$\neg$ rWIG20 $\rightarrow$ rEURPLN & $1.634[0.0511]^{*}$ & $4.168[0.0000]^{* * *}$ \\
\hline$\neg \mathrm{rEURPLN} \rightarrow \mathrm{rWIG} 20$ & $-1.087[0.8615]$ & $4.145[0.0000]^{* * *}$ \\
\hline$\neg \mathrm{rDAX} \rightarrow \mathrm{rWIG} 20$ & $1.505[0.0662]^{*}$ & $2.824[0.0024]^{\star * *}$ \\
\hline$\neg \mathrm{rWIG} 20 \rightarrow \mathrm{rDAX}$ & $1.595[0.0554]^{*}$ & $4.559[0.0000]^{* * *}$ \\
\hline
\end{tabular}

\section{Conclusions}

The results of the two approaches for testing the Granger causality, presented here for a daily closing values of the EURPLN exchange rate and the two corresponding stock indices - one for Germany as representing the Euro zone (DAX), the other for Poland (WIG20) - seem to be influenced by period and the method of testing. Economic intuition and previous results concerning similar analysis for the USDPLN exchange rate and the two representative indices for the U.S. and the Polish stock exchange suggested that the global crisis have changed the direction and strength of the causal relationship for the logarithmic returns, as measured by the linear Granger test of the Granger causality. There were differences in lack or presence of G-causality between the analysed pairs of variables, and seeming increase of the U.S. data influence during the crisis (perhaps a reflection of temporal changes in capital flows in the global economy).

Here, for the EURPLN exchange rate and the DAX and WIG20 stock index, we note much higher homogeneity of results - lack of causality before 
crisis, overall presence of two-side causality during the crisis - when the tests are applied to the volatility measure (2). Both the linear Granger test and the nonlinear Diks-Panchenko test give similar results (see Table 5 and the lower part of the Table 7).

Results of the linear Granger test for the logarithmic returns are different: this version of the test does not reject lack of linear causal relationship neither before the crisis nor during the crisis (see Table 3) with one exception of Granger-causality from the EURPLN towards WIG20 during the crisis. The Diks-Panchenko nonlinear test, on the other hand, does not reject lack of causality before the crisis, but strongly rejects it during the crisis (see upper part of the Table 7).

Additional computations for the instantaneous causality in the linear framework show that there is a feedback between all pairs of logarithmic returns and indicate Granger causality also for the volatility measure, even before the crisis (see Table 4 and 6). The possible explanation of this difference between (lagged) causality test and instantaneous causality test merits further attention - perhaps partial explanation could be based on possible analysis of efficiency of the markets, as it seems that changes in returns and volatility seem to influence the other instrument at once, on the same day. The future research can also take into account indirect influence of other variables (e.g., the U.S. indices) on causal relationship between the two European instruments.

\section{References}

Bauwens, L., Pohlmeier, W., Veredas, D. (2008), High Frequency Financial Econometrics. Recent Developments, Physica-Verlag A Springer Company, Heidelberg.

Bauwens, L., Rime, D., Succarat, G. (2008), Exchange Rate Volatility and the Mixture of Distribution Hypothesis, in Bauwens, L., Pohlmeier, W., Veredas, D., High Frequency Financial Econometrics. Recent Developments, Physica-Verlag A Springer Company, Heidelberg, 7-29.

Brooks, Ch. (2008), Introductory Econometrics for Finance, 2nd ed., Cambridge University Press, New York.

Diks, C., Panchenko, V. (2006), A New Statistics and Practical Guidelines for Nonparametric Granger Causality Testing, Journal of Economic Dynamics and Control, 30, 1647-1669, DOI: http://dx.doi.org/10.1016/j.jedc.2005.08.008.

Hiemstra, C., Jones, J. D. (1994), Testing for Linear and Nonlinear Granger Causality in the Stock Price-volume Relation, Journal of Finance, 49(5), 1639-1664, DOI: http://dx.doi.org/10.2307/2329266.

Matuszewska, A., Witkowska, D. (2007), Wybrane aspekty analizy kursu euro/dolar: Modele autoregresyjne z rozkładami opóźnień i sztuczne sieci neuronowe (Some Aspects of the EuroUSD Exchange Rate Analysis: ADL Models and Neuron Network), Metody ilościowe w badaniach ekonomicznych VIII, Modele ekonometryczne, 203-212. 
Osińska, M. (2008), Ekonometryczna analiza zależności przyczynowych (Econometric Analysis of Causal Relationships), Wydawnictwo Naukowe Uniwersytetu Mikołaja Kopernika, Torun.

Osińska, M. (2011), On the Interpretation of Causality in Granger Sense, Dynamic Econometric Models, 11, 129-139.

Syczewska, E. M. (2010a), Increase of Exchange Rate Risk During Current Crisis, Roczniki Kolegium Analiz Ekonomicznych, 21, 99-122.

Syczewska, E. M. (2010b), Changes of Exchange Rate Behaviour During and After Crisis, in Metody ilościowe w badaniach ekonomicznych (Quantitative Methods in Economics), $11,145-157$.

Syczewska, E. M. (2013), On Exchange-rate Model with Stock Indices as Additional Regressors (During and After Crisis), presented at the international conference „CEST'2013. Current Economic and Social Topic International Colloquium, focused on Gender Disparities and Financial Market Analysis", May 23-24, 2013 r., Warsaw.

Syczewska, E. M. (2014), Przyczynowość w sensie Grangera - wybrane metody (The Granger causality - selected tools), Metody Ilościowe w Badaniach Ekonomicznych, 15(4), 169-180.

\section{EURPLN, DAX i WIG20: testy przyczynowości Grangera przed i podczas kryzysu}

Z a rys treści. Artykuł dotyczy przyczynowości w sensie Grangera zastosowanej do dziennych notowań kursu EURPLN oraz odpowiadających mu dwu indeksów - DAX i WIG20. Przedstawia wyniki zastosowania dwu wariantów liniowego testu Grangera w tym wariantu dla tzw. natychmiastowej przyczynowości - oraz nieliniowego testu DiksaPanchenki do logarytmicznych zwrotów badanych instrumentów oraz do miary odzwierciedlającej zmienność dzienną $r_{t}=\ln \left(\frac{P_{\max , t}}{P_{\min , t}}\right)$ jako proporcję minimalnych i maksymalnych notowań w dniu $t$. Różnice pomiędzy wynikami testu przyczynowości dla par zwrotów pomiędzy okresem poprzedzającym kryzys a okresem kryzysu nie są tak duże jak w badaniach dotyczących kursów i indeksów polskich i amerykańskich. Widoczna jest natomiast różnica pomiędzy wynikami dla zwrotów i dla miary zmienności.

S ł o w a k l u c z o w e: kurs walutowy, indeksy giełdowe, kryzys finansowy, ryzyko, przyczynowość w sensie Grangera, natychmiastowa przyczynowość, test Diksa-Panchenki. 